\title{
PROTECTIVE ROLE OF TELMISARTAN, CANDESARTAN AND OLMESARTAN ON COLD RESTRAINT STRESS -INDUCED GASTRIC ULCER IN RATS: INFLUENCE OF PPAR $\Gamma$ MRNA
}

\author{
Mona K. Tawfik * \\ Department of Pharmacology, Faculty of Medicine, Suez Canal University, Ismailia, Egypt
}

\begin{abstract}
Certain angiotensin receptor blockers (ARBs) possess peroxisome proliferators activator receptor gamma (PPAR- $\gamma$ ) activating potency that correlates with their degree of lipophilicity. So, the present study was conducted to evaluate the gastro-protective effect of telmisartan; the well-established ARB with the highest lipophilicity; on cold-restraint stress (CRS) -induced gastric ulcer models in rats, in comparison with other ARBs (candesartan and olmesartan), to justify the possible role of PPAR- $\gamma$ agonistic activity of ARBs in gastroprotection. Rats were assigned to sham control, cold-restraint stress, telmisartan, candesartan and olmesartan pre-treated groups $(10 \mathrm{mg} / \mathrm{kg}$ each for 15 days $)$. Pre-treatment with telmisartan, candesartan or olmesartan for 15 days induced elevation in PPAR- $\gamma$ mRNA associated with an increase in the defensive factors by virtue of its ulcer score, antioxidant enzyme activities as well as the prostaglandin $\mathrm{E}_{2}\left(\mathrm{PGE}_{2}\right)$ level and a decreased in the aggressive factors like malondialdehyde (MDA), free acidity, pepsin, myeloperoxidase (MPO) activity and TNF- $\alpha$ level. Moreover, telmisartan provided superior gastroprotection to candesartan and olmesartan. In conclusion, telmisartan, candesartan and olmesartan could protect rats' gastric mucosa from CRS -induced ulcerations most possibly through its antioxidant activity, anti-secretory actions and enhanced mucosal protection. Activation of PPAR- $\gamma$ might be one potential $\mathrm{AT}_{1}$-independent mechanism of action that explains the superiority of telmisartan in gastroprotection than candesartan and olmesartan.
\end{abstract}

Key words: Cold-restraint stress, Telmisartan, Candesartan, Olmesartan, oxidative stress, TNF- $\alpha$, prostaglandin $\mathrm{E}_{2}$

\section{INTRODUCTION}

Peptic ulcer, encompassing gastric and duodenal ulcers, is the most common gastrointestinal tract disorder in clinical practice (Sumbul et al., 2011), and hence, some researchers consider it a new plague of the twenty-first century (O'Malley, 2003). Moreover, peptic ulcer has been one of the leading causes of gastrointestinal surgery, with high morbidity and mortality rates (Sumbul et al., 2011).

Cold-restraint stress (CRS) is a commonly used and clinically relevant experimental model for acute gastric damage (Bregonzio et al., 2003). The pathological basis for the development of this lesion has been postulated to be multifactor such as increased gastric acid secretion, inhibition of gastric mucosal prostaglandin synthesis, disruption of gastric mucosal barrier, reduction of gastric mucosal blood flow, inhibition of gastric mucus and bicarbonate secretion (Alsarra et al., 2010; Manas et al., 2010). Another mechanism of gastric damage is release of myeloperoxidase enzymes, various cytokines like TNF- $\alpha$ and interleukin (Muthuraman and Sood, 2010) and development of oxidative stress (Singh et al., 2008; Oyagi et al., 2010). 
An increasing body of evidence indicates that Angiotensin II (Ang II) has been accepted as a fundamental stress hormone in the body (Bregonzio et al., 2008; Zhu et al., 2011). Most of the established effects of Ang II appear to be mediated through the Ang II type $1\left(\mathrm{AT}_{1}\right)$ receptor. Angiotensin receptor blockers (ARBs) have been used widely in the clinic as antihypertensive agents. More recently, treatment with some ARBs has been found to be effective in the treatment of stress-related disorders (Saavedra and Benicky, 2007; Pavel $\boldsymbol{e t}$ al., 2008).

In the last few years, it has become evident that the therapeutic effects of PPAR- $\gamma$ ligands reach far beyond their use as insulin sensitizers. PPAR- $\gamma$ has been implicated as a regulator of cellular inflammatory and ischemic responses (Pershadsingh, 2004). It became also apparent that the pleiotropic effects of PPAR- $\gamma$ stimulation included also its protective action against gastric mucosal damage; and this protection involved endogenous prostaglandins (PG), nitric oxide (NO) and attenuation of the expression and release of proinflammatory cytokines (Wada et al., 2004; Brzozowski et al., 2005).

Certain ARBs possess PPAR- $\gamma$ activating potency that correlates with their degree of lipophilicity (Schupp et al., 2004, 2006). So, PPAR-activating ARBs by their dual functions (AT1 receptor antagonism and PPAR- $\gamma$ activation) are suggested to be efficacious for protection against gastric ulcers.

Telmisartan is a well-established ARB with the highest lipophilicity and affinity to PPAR- $\gamma$ than candesartan and olmesartan (Schupp et al., 2004). Hence, the aim of the present study was to evaluate the gastro-protective effect of telmisartan on CRS-induced gastric ulcer models in rats, in comparison with other ARBs (candesartan and olmesartan), to justify the possible role of PPAR- $\gamma$ agonistic activity of ARBs in gastro-protection.

\section{MATERIALS AND METHODS}

\section{Experimental animals:}

Fifty adult male albino rats weighing $200 \pm 10 \mathrm{~g}$ were used in this study. They were purchased from the Egyptian Organization for Biological Products and Vaccines (Egypt), and allowed free access to food and water ad libitum. They were kept under constant conditions with 12/12 h light/dark cycles and left for acclimatization for one week before the start of the study. All experimental procedures were approved by the Institutional Animal Care and Use Committee in the Suez Canal University.

\section{Drugs:}

Telmisartan (Boehringer Co., Germany), Candesartan (Astra Zeneca Co., Egypt) and Olmesartan (Sankyo Co., Japan) were used. Telmisartan was given orally once a day by gastric tube at a dose of $10 \mathrm{mg} / \mathrm{kg}$ (Kakadiya et al., 2010), Candesartan was given orally once a day by gastric tube at a dose of $10 \mathrm{mg} / \mathrm{kg}$ (Bregonzio et al., 2008) and Olmesartan was given orally once a day by gastric tube at a dose of $10 \mathrm{mg} / \mathrm{kg}$ (Sukumaran et al., 2010). All drugs were dissolved in distilled water and given for 15 days.

Pyloric ligation was performed to all animals in all groups in order to collect the gastric juice; animals were given water but no food for $24 \mathrm{~h}$. before the experiment. Rats were anaesthetized with i.p. injection of urethane in a dose of $1.25 \mathrm{mg} / \mathrm{kg}$ (Iwamoto et al., 1987). Pylorus ligation was performed by a small midline incision below the xiphoid process. Pyloric portion of the stomach was lifted slightly and ligated avoiding traction to the pylorus and damage to the blood supply. The stomach was replaced carefully, and abdomen was closed by 
interrupted sutures. During the post-operative period, animals were deprived of both food and water (Manas et al., 2010).

\section{Experimental Protocol}

Rats were randomly divided into 5 groups, 10 per each. Rats were assigned to Sham operated control group (received distilled water orally daily for 15 days; on day 16, they were subjected to pyloric ligation and were used as normal control group), CRS control group, telmisartan, candesartan and olmesartan treated groups (received distilled water, telmisartan, candesartan or olmesartan, respectively, orally daily for 15 days; on day 16 all animals were underwent pyloric ligation and CRS).

\section{Induction of gastric ulceration and collection of gastric juice}

Cold-restraint stress was performed to animals in all groups except the sham group. Rats were immobilized in individual restraint boxes and immersed up to the depth of the xiphoid process in a $\left(4 \pm 1^{\circ} \mathrm{C}\right)$ water bath for $3.5 \mathrm{~h}$ (Dekanski et al., 2009). At the end of this period, blood samples were collected via the tail veins, then rats were sacrificed; abdomen was opened by the midline incision. The esophageal region was ligated to prevent the loss of gastric fluid and the stomach was dissected out. The gastric contents were drained into a small beaker. The actual volume of gastric contents was recorded and $\mathrm{pH}$ was determined. The contents were subjected to centrifugation at $2000 \mathrm{rpm}$ for $10 \mathrm{~min}$. The supernatant was subjected to analysis for total acidity and free acidity.

\section{Assessment of gastric mucosal lesions}

The stomach was removed, inflated with $10 \mathrm{ml}$ saline and fixed with $4 \%$ neutral formalin for $30 \mathrm{sec}$. This procedure fixed only the outer layer of the stomach tissue rendering the inner lining of the stomach quite smooth, facilitating examination. The stomach was cut open along the gastric greater curvature. The gastric mucosa was carefully examined with 10time magnifications for the presence of linear breaks (erosions) at the mucosal surface of the glandular part to determine the ulcer index (UI). The number and severity of gastric lesions were evaluated according to the following rating scale: 0 - no lesion, 1 - mucosal edema and petechiae, 2 - from 1 to 5 small lesions (1-2 mm), 3 - more than 5 small lesions or 1 intermediate lesion (3-4 mm), $4-2$ or more intermediate lesions or one gross lesion (greater than $4 \mathrm{~mm}$ ) and 5 - perforated ulcers. The sum of the total scores divided by the number of animals in the group was expressed as the UI \pm S.D. (Dekanski et al., 2009).

Then, stomach tissues were divided into two portions. The first one was immediately frozen at $-80^{\circ} \mathrm{C}$ for the different biochemical assays, while the other part was embedded in $10 \%$, neutral buffered formalin and processed to perform histopathological assay, where 4-6 $\mu \mathrm{m}$ thick paraffin sections were subjected to the hematoxyline and eosin stain.

\section{Biochemical measurements:}

For estimation of the different oxidative stress parameters as well as the antioxidant enzyme activities, a part of the stomach $(0.25 \mathrm{~g})$ was ice-cooled, homogenized in $2.5 \mathrm{ml}$ phosphate buffer saline (PBS; pH 7.4), and then centrifuged at $3000 \mathrm{xg}$ for $15 \mathrm{~min}$ at $4^{\circ} \mathrm{C}$. The supernatant was collected and used for:

\section{Biochemical analysis of oxidative markers:}

Estimation of thiobarbituric acid reactive substance (TBARS) in stomach homogenates as a measure of MDA content:

Lipid peroxidation was done spectrophotometrically (Shimadzu Co, Japan) as described by Preuss et al. (1998). 


\section{Estimation of reduced glutathione (GSH).}

GSH was measured spectrophotometrically (Shimadzu Co, Japan) according to the method of Ellman (1970).

\section{Estimation of superoxide dismutase (SOD) activity.}

SOD activity was assayed in stomach homogenate spectrophotometrically (Shimadzu Co, Japan) using SOD assay kits (Bio-Diagnostic, Egypt) as described by Marklund (1992).

\section{Estimation of catalase (CAT) activity.}

The activity of CAT was determined in stomach homogenate spectrophotometrically using CATA assay kits (Bio-Diagnostic, Egypt) as reported by Aebi (1984).

\section{Biochemical analysis of gastric juice}

\section{Estimation of $\mathrm{pH}$, total and free acidity of gastric juice:}

The gastric juice was collected, centrifuged, and the clear supernatant was analyzed for $\mathrm{pH}$ as well as total and free acidity using the method of Kulkarni (1999). Briefly, one ml of gastric juice supernatant was diluted to $10 \mathrm{ml}$ using distilled water. The solution was titrated against $0.01 \mathrm{~N}$ sodium hydroxide using topfer's reagent as an indicator till the colour became orange. The volume of $\mathrm{NaOH}$ corresponds to free acidity. Then, 2 to 3 drops of phenolphethalin solution were added, and titration was continued until a definite red ting reappears. Again, the total volume of alkali added was noted as it corresponded to the total acidity. Acidity was calculated by using the formula:

Acidity $=$ volume of $\mathrm{NaOH}$ x concentration of $\mathrm{NaOH} /$ volume of sample

\section{Estimation of Pepsin activity}

Pepsin activity was measured by the method of Debnath et al. (1974). Briefly, one ml of diluted gastric juice was mixed with $2 \%$ haemoglobin solution in $0.06 \mathrm{M} \mathrm{HCl}$ and incubated for $20 \mathrm{~min}$. Then, $0.6 \mathrm{M}$ ice cold trichloroacetic acid was added. Later, the solution was centrifuged and the supernatant was mixed with Reagent C (alkaline copper sulphate solution) and Reagent E (diluted Folin reagent), and the optical density was measured at $610 \mathrm{~nm}$ against a blank of distilled water.

\section{Estimation of prostaglandin $\mathrm{E}_{2}\left(\mathrm{PGE}_{2}\right)$}

Gastric mucosa was scrapped, homogenized in $2 \mathrm{ml}$ normal saline containing $0.1 \mathrm{M}$ dithiothreitol and centrifuged at $2000 \mathrm{~g}$ for $10 \mathrm{~min}$ at room temperature. The supernatant was used for determination of $\mathrm{PGE}_{2}$ level by enzyme-linked immunosorbent assay (ELISA) using $\mathrm{PGE}_{2}$ immunoassay kit (R\&D Systems, USA) (Heeba et al., 2009).

\section{Estimation of TNF- $\alpha$.}

Stomach tissues were homogenized using 0.1 M phosphate buffer ( $\mathrm{pH}$ 7.4) containing $0.05 \%(\mathrm{w} / \mathrm{v})$ sodium azide at $4^{\circ} \mathrm{C}$. Homogenates were sonicated for $20 \mathrm{sec}$. and centrifuged (2000g for $10 \mathrm{~min}$. at $4^{\circ} \mathrm{C}$ ). The resulting supernatants were used for assaying TNF- $\alpha$ level using ELISA (BioSource Europe S.A. Belgium) as described by Mizutani et al. (2003).

\section{Estimation of myloperoxidase (MPO) activity:}

Assay of MPO activity was described by Mizutani et al., (2003). Briefly, stomach tissue samples $(0.5 \mathrm{gm})$ were homogenized in $10 \mathrm{ml}$ of homogenization buffer ( $\mathrm{pH} 4.7$ ) [0.1 $\mathrm{mol} / \mathrm{L} \mathrm{NaCl}, 0.02 \mathrm{~mol} / \mathrm{L} \mathrm{NaPO}_{4}$ and $0.015 \mathrm{~mol} / \mathrm{L}$ EDTA] and centrifuged at $260 \mathrm{x} \mathrm{g}$ for 10 min.; pellets underwent hypotonic lysis in $0.2 \% \mathrm{NaCl}$ solution followed 1 min. later by addition of an equal volume of solution containing (1.6\% NaCl and $5 \%$ glucose). After further 
centrifugation, the pellet was then suspended in $50 \mathrm{mM}$ phosphate buffer $\mathrm{pH} 5.4$; containing $0.5 \%$ hexadecyltrimethylammonium bromide (HETAB). One milliliter aliquots of the suspension were frozen and thawed three cycles in liquid nitrogen, then centrifuged for 15 min. at $3000 \mathrm{~g}$. The pellet was discarded. MPO activity was assayed by measuring the change in optical density at $450 \mathrm{~nm}$ using tetramethylbenzidine, as a substrate $(1.5 \mathrm{mmol} / \mathrm{L})$ and $\mathrm{H}_{2} \mathrm{O}_{2}$ $(0.5 \mathrm{mmol} / \mathrm{L})$. Results were expressed as MPO relative units $/ 100 \mathrm{mg}$ tissue. One unit of MPO activity was defined as the quantity of enzyme degrading $1 \mathrm{mmol}$ peroxide at $25^{\circ} \mathrm{C}$. The activity of purified known human neutrophil MPO was used as a standard (Sigma Chemical Co, USA).

\section{RT-PCR for detection of PPAR- $\gamma$ mRNA.}

Total RNA was isolated from gastric tissues using RNA extraction kit (Qiagen, Germany). The concentration of the extracted RNA was measured by NanoDrop ND-1000 (NanoDrop Tech., Wilmington, USA). Specific primers for rat PPAR- $\gamma$ cDNA fragment: Sense: 5' TTTTCAAGGGTGCCAGTTTC3', Antisense: 5' CTGTGACAATCTGCCTGAG3' were used according to the published rat PPAR- $\gamma$ cDNA sequence (accession No. AF156665 (Zhang $\boldsymbol{e t}$ al., 2010) and $\beta$-actin primers sense: 5'-ATGGATGATGATATCGCCGCG-3' antisense 5'-TGAAGGTAGTTTCGTGGATGC-3' were used. PCR was performed using one step RT-PCR kit (Qiagen, Germany). Cycling parameters for amplifying RT products were as follows: $94{ }^{\circ} \mathrm{C} 45 \mathrm{~s}, 58{ }^{\circ} \mathrm{C} 45 \mathrm{~s}, 72{ }^{\circ} \mathrm{C} 45 \mathrm{~s}$, for 30 cycles, and then extended at $72{ }^{\circ} \mathrm{C}$ for another $5 \mathrm{~min}$. After amplification, PCR products (product size 501) were electrophoresed on $1.2 \%$ agarose gel, stained with ethidium bromide, and photographed by using the gel documentation system (Bio Doc Analyze, Biometra).

\section{Statistical analysis:}

Results were collected and expressed as means \pm SD. Results were analyzed using the Statistical Package for the Social Sciences, version 15 (SPSS Software, SPSS Inc., Chicago, USA). One-way analysis of variance (ANOVA) followed by Duncan's post-hoc test was used to test the significance of the difference between quantitative variables. $\mathrm{P}$ value $\leq 0.05$ was used as criterion of significance.

\section{RESULTS}

\section{Effect of various pretreatments on oxidative stress}

Table1. showed that CRS exposure induced oxidative stress in stomach homogenates in the form of significant increase $(\mathrm{P} \leq 0.05)$ of MDA content associated with significant $(\mathrm{P} \leq$ 0.05) reduction in SOD, GSH and CAT activities in comparison with the sham control group. These deleterious effects associated with CRS exposure were improved by treatment with telmisartan, candesartan or olmesartan in comparison with CRS control group $(P \leq 0.05)$. It was obvious that, telmisartan administration was associated with significant reduction in these oxidative markers in comparison to those afforded by candesartan and olmesartan treatment $(\mathrm{P} \leq 0.05)$; indicating that telmisartan offered more protective effects than candesartan or olmesartan. 
Table 1. Effect of telmisartan, candesartan, and olmesartan on MDA, \& GSH contents, as well as SOD, and CAT activities in CRS-induced gastric ulceration.

\begin{tabular}{|c|c|c|c|c|c|}
\hline Groups & \multicolumn{1}{|c|}{$\begin{array}{c}\text { Sham } \\
\text { control }\end{array}$} & $\begin{array}{c}\text { Cold- } \\
\text { restraint } \\
\text { stress. }\end{array}$ & $\begin{array}{c}\text { Telmisartan } \\
\text { treated }\end{array}$ & $\begin{array}{c}\text { Candesartan } \\
\text { treated }\end{array}$ & $\begin{array}{c}\text { Olmesartan } \\
\text { treated }\end{array}$ \\
\hline $\begin{array}{c}\text { MDA } \\
\text { (nmol/g } \\
\text { protein) }\end{array}$ & $4.88 \pm 1.3$ & $19.8 \pm 2.3$ & $9.2 \pm 1.8^{\#}$ & $12.3 \pm 1.7^{\#} \dagger$ & $15.3 \pm 3.8^{\#} \dagger$ \\
\hline $\begin{array}{c}\text { GSH } \\
(\mu \mathrm{mol} / \mathrm{g} \\
\text { protein) }\end{array}$ & $5.58 \pm 1.2$ & $2.21 \pm 0.98$ & $4.88 \pm 1.27^{\#}$ & $3.78 \pm 1.01^{\#} \dagger$ & $3.27 \pm 0.62^{\#} \dagger$ \\
\hline $\begin{array}{c}\text { SOD } \\
(\mathrm{U} / \mathrm{mg} \\
\text { protein) }\end{array}$ & $67.16 \pm 15.9$ & $23.8 \pm 10.8^{*}$ & $58.2 \pm 14.9^{\#}$ & $43.3 \pm 10.0^{\#} \dagger$ & $33.8 \pm 6.0^{\#} \dagger$ \\
\hline $\begin{array}{c}\text { CATA } \\
(\mathrm{U} / \mathrm{mg} \\
\text { protein) }\end{array}$ & $20.7 \pm 5.7$ & $7.2 \pm 2.05^{*}$ & $17.4 \pm 2.8^{\#}$ & $12.0 \pm 2.4^{\#} \dagger$ & $11.03 \pm 1.8^{\#} \dagger$ \\
\hline
\end{tabular}

$\mathrm{n}=10$, Values are presented as means \pm SD

${ }^{*}$ Significantly different from sham control group $\mathrm{P} \leq 0.05$

\# Significantly different from cold-restraint stress control group $\mathrm{P} \leq 0.05$

$\uparrow$ Significantly different from telmisartan treated group $\mathrm{P} \leq 0.05$

Effect of various pretreatments on the gastric juice analysis

Cold- restraint stress led to a significant elevation $(\mathrm{P} \leq 0.05)$ in total, free acidity and pepsin activity as well as significant reduction in $\mathrm{pH}$ of gastric juice in comparison with the sham control group. Treatment with telmisartan, candesartan or olmesartan significantly $(\mathrm{P} \leq$ 0.05) reduced total, free acidity and pepsin activity as compared to the non-treated group. Additionally, telmisartan had a more ameliorating effect on the increased pepsin activity than candesartan or olmesartan (Table 2).

Table 2. Effect of telmisartan, candesartan, and olmesartan on $\mathrm{pH}$, total acidity, free acidity and pepsin activities in CRS-induced gastric ulceration.

\begin{tabular}{|c|c|c|c|c|c|}
\hline Groups & Sham control & $\begin{array}{c}\text { Cold-restraint } \\
\text { stress. }\end{array}$ & $\begin{array}{c}\text { Telmisartan } \\
\text { treated }\end{array}$ & $\begin{array}{c}\text { Candesartan } \\
\text { treated }\end{array}$ & $\begin{array}{c}\text { Olmesartan } \\
\text { treated }\end{array}$ \\
\hline $\mathrm{PH}$ & $2.37 \pm 0.47$ & $1.76 \pm 0.42^{*}$ & $2.36 \pm 0.60^{\#}$ & $2.25 \pm 0.79^{\#}$ & $2.11 \pm 0.43^{\#}$ \\
\hline $\begin{array}{c}\text { Total acidity } \\
(\mathrm{mq} / \mathrm{l})\end{array}$ & $59.8 \pm 8.9$ & $83.3 \pm 16.6^{*}$ & $67.1 \pm 8.8^{\#}$ & $70.4 \pm 10.3^{\#}$ & $72.3 \pm 11.35^{\#}$ \\
\hline $\begin{array}{c}\text { Free acidity } \\
(\mathrm{mq} / \mathrm{l})\end{array}$ & $37.8 \pm 9.2$ & $65.8 \pm 7.8^{*}$ & $48.1 \pm 9.4^{\#}$ & $51.3 \pm 9.4^{\#}$ & $53.3 \pm 9.4^{\#}$ \\
\hline $\begin{array}{c}\text { Pepsin } \\
\text { activity } \\
(\mu \mathrm{g} / \mathrm{ml})\end{array}$ & $4.4 \pm 0.9$ & $8.1 \pm 1.12^{*}$ & $4.7 \pm 1.18^{\#}$ & $5.52 \pm 0.6^{\#} \dagger$ & $6.2 \pm 1.14^{\#} \dagger$ \\
\hline
\end{tabular}

$\mathrm{n}=10$, Values are presented as means $\pm \mathrm{SD}$

${ }^{*}$ Significantly different from sham control group $\mathrm{P} \leq 0.05$

\# Significantly different from cold-restraint stress control group $\mathrm{P} \leq 0.05$

$\uparrow$ Significantly different from telmisartan treated group $\mathrm{P} \leq 0.05$

\section{Effect of various pretreatments on TNF- $\alpha$ levels and MPO activities}

Cold-restraint stress induced a significant elevation in the TNF- $\alpha$ concentration and MPO activities $(\mathrm{P} \leq 0.05)$ as compared to the sham control group. These changes were 
significantly ameliorated by treatment with telmisartan, candesartan or olmesartan. It was obvious that, protection offered by telmisartan treatment was more than those of candesartan and olmesartan (Table 3).

Table 3. Effect of telmisartan, candesartan, and olmesartan on TNF- $\alpha$ concentration and MPO activities in CRS-induced gastric ulceration.

\begin{tabular}{|c|c|c|c|c|c|}
\hline Groups & Sham control & $\begin{array}{c}\text { Cold- } \\
\text { restraint } \\
\text { stress. }\end{array}$ & $\begin{array}{c}\text { Telmisartan } \\
\text { treated }\end{array}$ & $\begin{array}{c}\text { Candesartan } \\
\text { treated }\end{array}$ & $\begin{array}{c}\text { Olmesartan } \\
\text { treated }\end{array}$ \\
\hline $\begin{array}{c}\text { TNF- } \alpha \\
\text { (ng/g protein) }\end{array}$ & $21 \pm 7$ & $204 \pm 34^{*}$ & $59 \pm 14^{\#}$ & $72 \pm 21^{\#} \dagger$ & $107 \pm 22^{\#} \dagger$ \\
\hline $\begin{array}{c}\text { MPO } \\
\text { (U/100 mg tissue })\end{array}$ & $0.35 \pm 0.09$ & $2.88 \pm 1.11^{*}$ & $0.94 \pm 0.24^{\#}$ & $1.5 \pm 0.32^{\#} \dagger$ & $1.72 \pm 0.25^{\#} \dagger$ \\
\hline
\end{tabular}

$\mathrm{n}=10$, Values are presented as means $\pm \mathrm{SD}$

* Significantly different from sham control group $\mathrm{P} \leq 0.05$

${ }^{\text {\# }}$ Significantly different from cold-restraint stress control group $\mathrm{P} \leq 0.05$

$\dagger$ Significantly different from telmisartan treated group $\mathrm{P} \leq 0.05$

Effect of various pretreatments on $\mathrm{PGE}_{2}$ concentration

Fig.1. showed that, CRS control group exhibited significant $(\mathrm{P} \leq 0.05)$ reduction in $\mathrm{PGE}_{2}$ concentration in comparison to sham control group. However, treatment with telmisartan, candesartan or olmesartan significantly $(\mathrm{P} \leq 0.05)$ restored $\mathrm{PGE}_{2}$ level as compared to the non-treated group. Additionally, it was obvious that telmisartan had the superiority in restoring $\mathrm{PGE}_{2}$ concentration than candesartan and olmesartan.

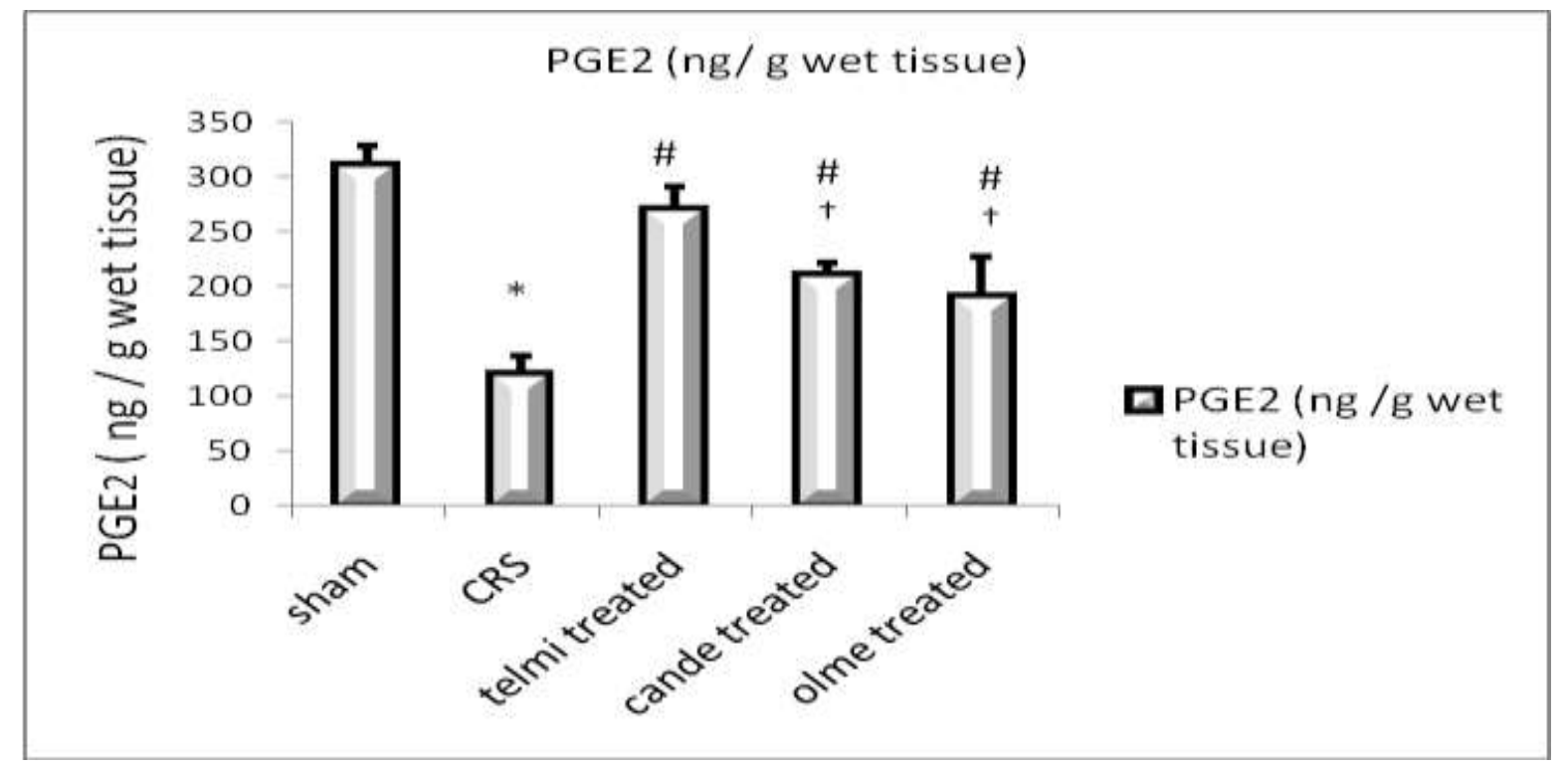

Fig.1. Effect of telmisartan, candesartan, and olmesartan on $\mathrm{PGE}_{2}$ (ng/g wet tissue) in CRSinduced gastric ulceration. Values are expressed as means \pm S.D. $(n=10)$, analyzed by one-way ANOVA followed by Duncan multiple comparisons test. ${ }^{*} p \leq 0.05$ compared to sham control group. ${ }^{\#} \mathrm{p} \leq 0.05$ compared to cold-restraint stress group. $\dagger \mathrm{p} \leq 0.05$ compared to telmisartan treated group. 


\section{Effect of various pretreatments on the gastric mucosal lesion formation}

Gastric histopathological results verified the serological results. Fig.2- $\mathrm{I}_{\mathrm{b}}$ showed that, CRS control group exhibited macroscopic gastric mucosal lesions, that was confined to the glandular part of the stomach with petechial bleeding, associated with widespread damage of the surface epithelium with many cells sloughed off into the gastric lumen, moderate lymphocytic inflammatory infiltrate of the lamina propria, moderate congestion, and mild hypertrophy of the muscle layer (Fig. $3_{\mathrm{b}}$ ). These mucosal lesions were accompanied by significant $(\mathrm{P} \leq 0.05)$ elevation in mean ulcer index in comparison with the sham control group (Fig.2-II). These deleterious effects associated with CRS exposure were ameliorated by treatment with either telmisartan (Fig.2- $\mathrm{I}_{\mathrm{c}}, 3_{\mathrm{c}}$ ), candesartan (Fig.2- $\mathrm{I}_{\mathrm{d}}, 3_{\mathrm{d}}$ ) or olmesartan (Fig.2$\left.\mathrm{I}_{\mathrm{e}}, 3_{\mathrm{e}}\right)$. It was obvious that treatment with telmisartan was associated with significant $(\mathrm{P} \leq$ 0.05) reduction of mean ulcer index than candesartan and olmesartan (Fig.2-II).

\section{Effect of various pretreatments on PPAR- $\gamma$ mRNA}

As seen in Fig. 4, PPAR- $\gamma$ mRNA levels were decreased in stomach homogenates of CRS rats (Lanes 5-6) as compared to the Sham control group (Lanes 1). Treatments with telmisartan (Lanes 7-8), candesartan (Lanes 3-4) or olmesartan (Lane 2) induced elevation in PPAR- $\gamma$ mRNA levels. $\beta$-actin mRNA expression for each sample was used as internal control. The effect of telmisartan in such elevation was more evident than that of both candesartan and olmesartan. 
I a

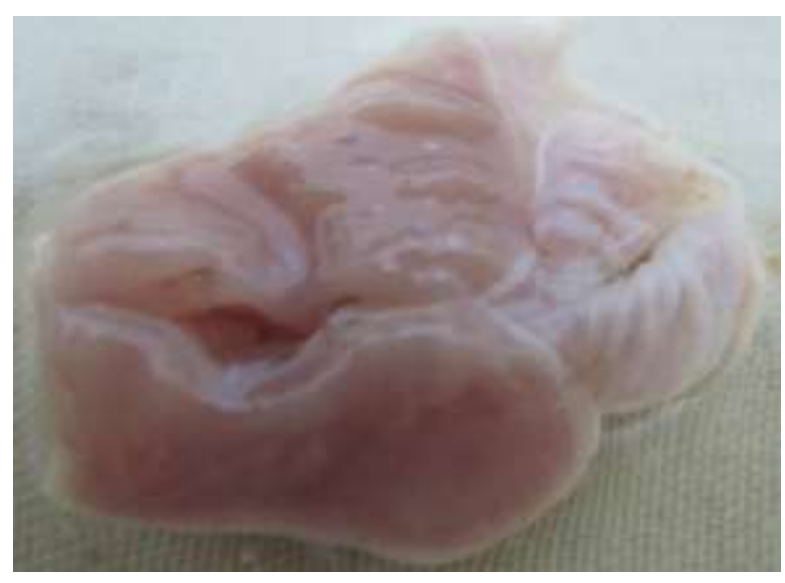

$\mathrm{c}$

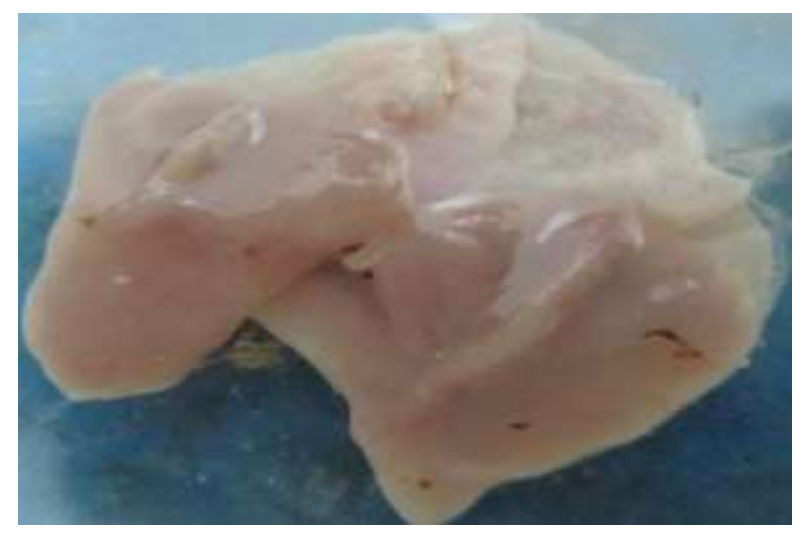

$\mathbf{e}$

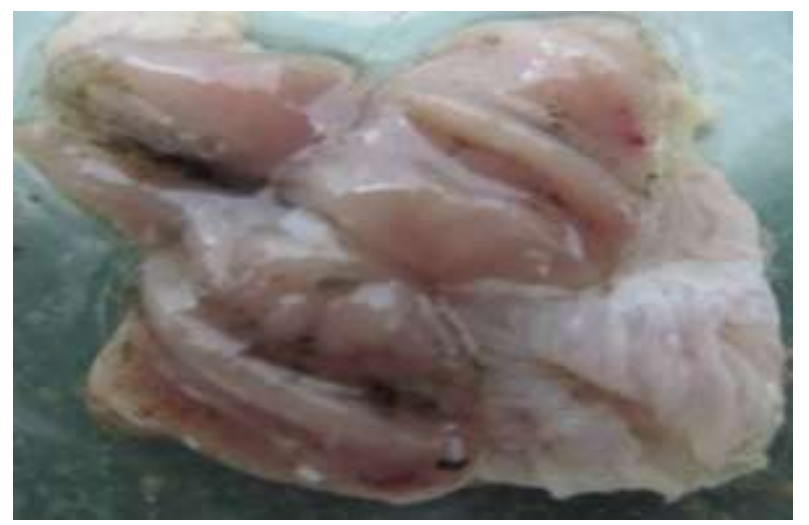

b

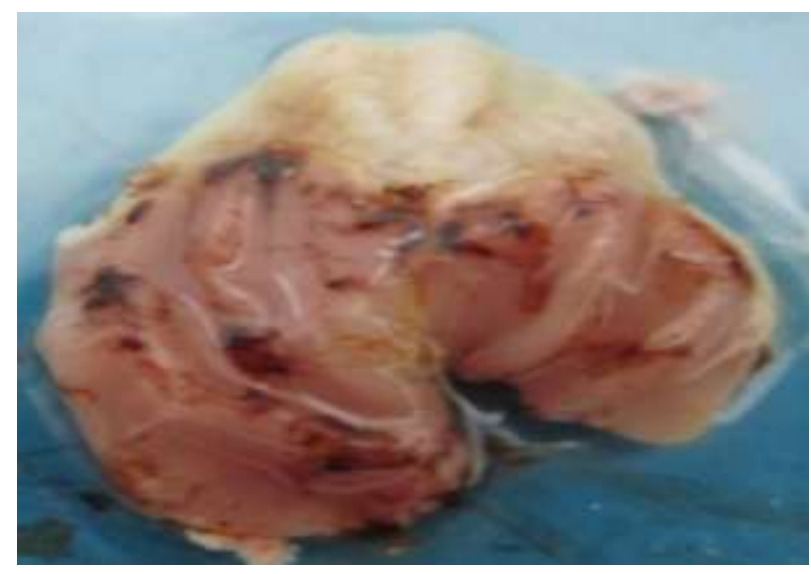

d

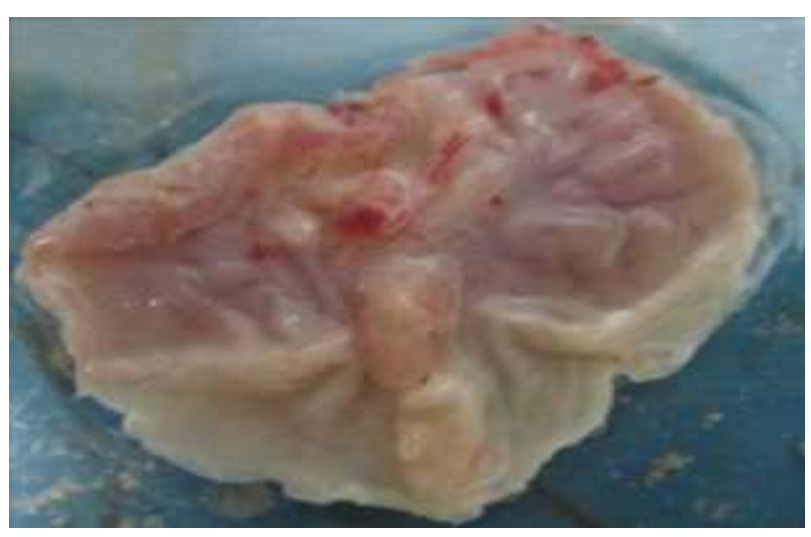

II

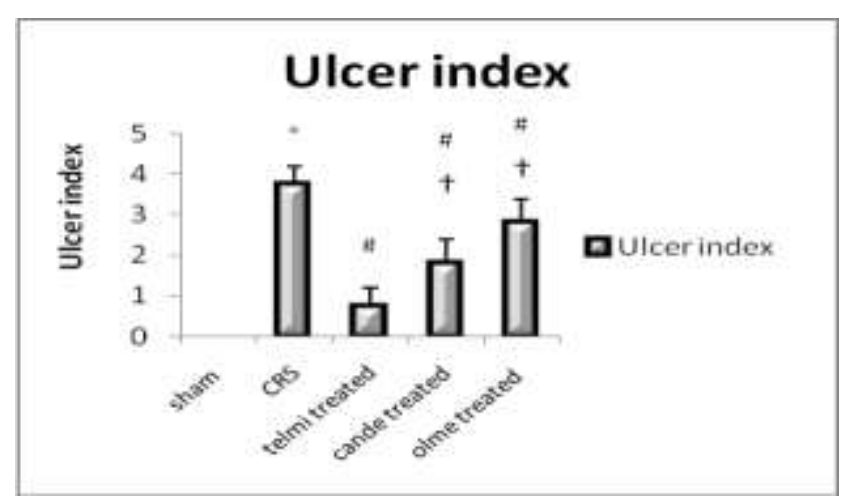

Fig.2. (I): Gastric mucosal lesions of the glandular portion of the stomach induced by CRS in a: sham control group, b: CRS control group, c: telmisartan treated group, d: candesartan treated group, and e: olmesartan treated group.

(II): Effect of telmisartan, candesartan, and olmesartan on ulcer index in CRS- induced gastric ulceration. Values are expressed as means \pm S.D. $(n=10)$, analyzed by one-way ANOVA followed by Duncan multiple comparisons test. ${ }^{*} \mathrm{p} \leq 0.05$ compared to sham control group. ${ }^{\#} \mathrm{p} \leq 0.05$ compared to cold-restraint stress group. $\dagger \mathrm{p} \leq 0.05$ compared to telmisartan treated group. 


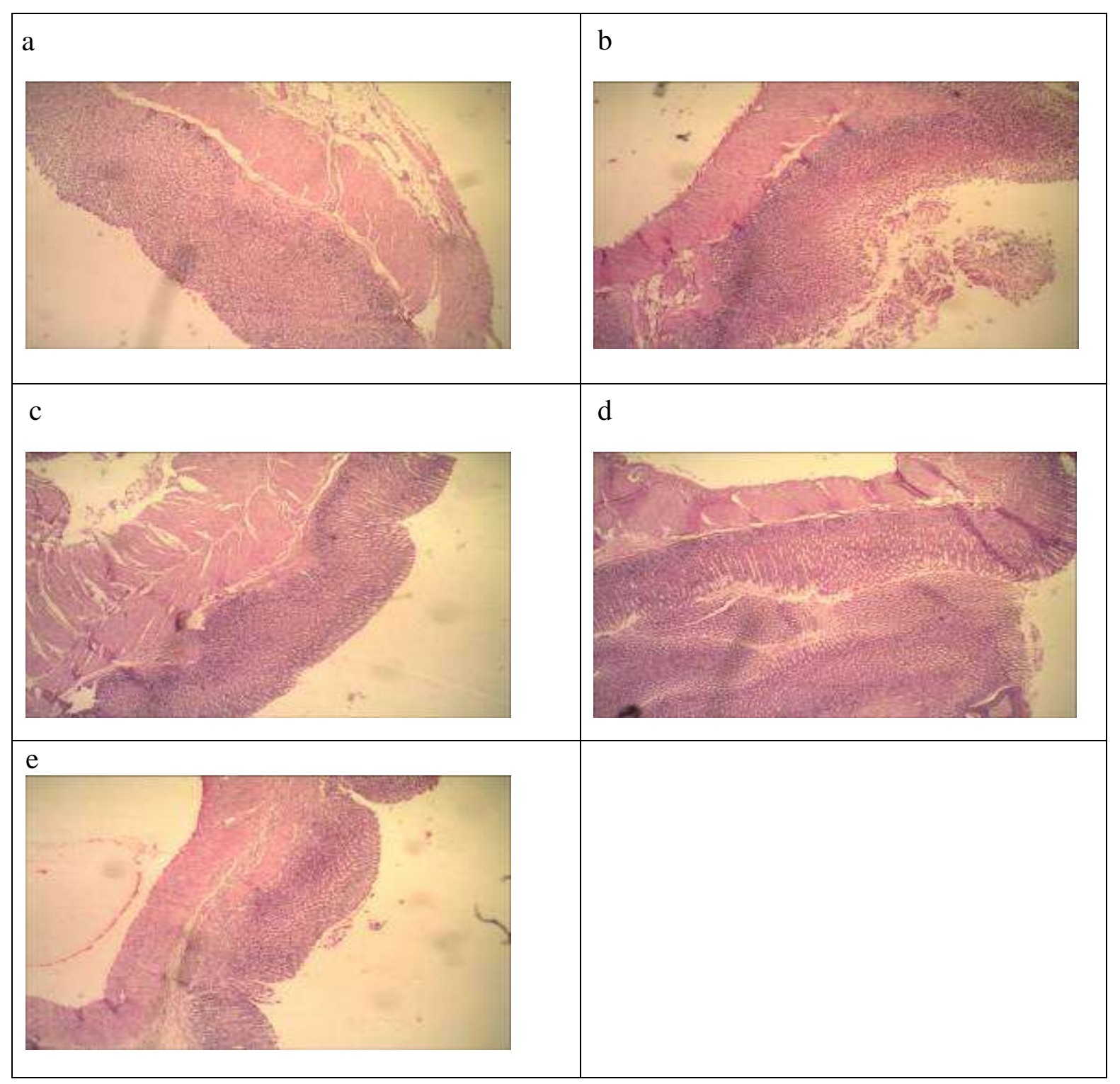

Fig.3. The histopathological picture of the gastric tissues from the experimental groups stained with hematoxylin \& eosin (H\&E). a: Sham control group showed intact mucosal lining, normal appearing gastric glands, with no erosions or ulceration and normal muscle layer. b: While stressed rats revealed widespread damage of the surface epithelium with many cells sloughed off into the gastric lumen, moderate lymphocytic inflammatory infiltrate of the lamina propria , moderate congestion, and mild hypertrophy of the muscle layer. Treatment with telmisartan was nearly similar to normal control group except that there was a light edema and mild hypertrophy of the muscle layer $(c)$. Treatment with candesartan showed intact mucosal lining with no erosions or ulceration, moderate endocrine cell hyperplasia, mild edema and minimal lymphocytic inflammatory inilftrate $(d)$. On the other hand, treatment with olmesartan showed mild congestion and superficial mucosal erosion with mild lymphocytic inflammatory infiltrate of the lamina propria $(e)$. (H \& E $40 \times)$. 
a)

$\begin{array}{lllllllllll}M & 1 & 2 & 3 & 4 & 5 & 6 & 7 & 8 & 9 & 10\end{array}$

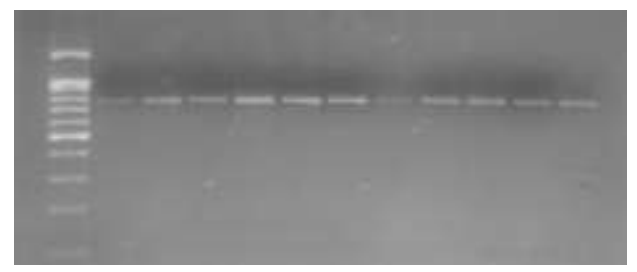

b)

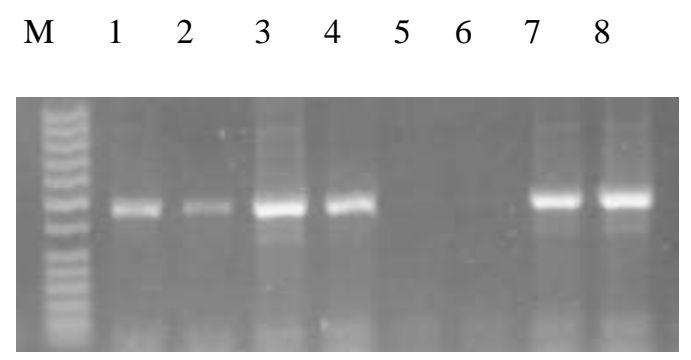

Fig.4. (a) $\beta$-Actin mRNA expression for each sample was used as internal control. (b) Expression of PPAR- $\gamma$ mRNA. Total RNA from stomach homogenate of CRSinduced gastric ulceration in rats was subjected to RT-PCR to evaluate PPAR- $\gamma$ mRNA expression. 100 bp marker, lane 1; Sham control, lane 2; Olmesartan treated, lane 3,4; Candesartan treated, lane 5,6; cold-restraint stress, lane 7,8; telmisartan treated.

\section{DISCUSSION}

The importance of stress erosions, which are reported worldwide, has stimulated considerable research because of the serious consequences of illness. From the experimental point of view, the use of restraint of small mammals has become the most popular method for producing acute stress ulcers in the stomach. It represents a tool to explain the importance of emotion and anxiety as factors in the evolution of human peptic ulcer. Therefore, in the current study, we used CRS-induced gastric ulcer models in rats to justify the possible role of PPAR- $\gamma$ agonistic activity and the dual functions of PPAR-activating ARBs in gastroprotection.

In the present study, rats exposed to CRS developed hemorrhagic lesions in the stomach that was assessed histo-pathologically by the ulcer index. This is accompanied by a significant increase of pro-inflammatory TNF- $\alpha$. The patho-physiological basis for the development of this lesion has been postulated to be multifactorial such as increased gastric acid secretion, inhibition of gastric mucosal PG synthesis, disruption of gastric mucosal barrier, inhibition of gastric mucus and bicarbonate secretion (Li et al., 2006; Dekanski et al., 2009), and free radicals formation (Brzozowski et al., 2007; Konturek et al., 2009; Bogdanova et al., 2010).

It is well known that the pathogenesis of stress-induced gastric lesions includes the generation of reactive oxygen species (ROS) that seem to play an important role, namely due to generation of lipid peroxides, accompanied by impairment of antioxidative enzyme activity of cells (Agnihotri et al., 2007; Banerjee et al., 2008; Muthuraman and Sood , 2010; Venkat et al., 2011). Our findings strongly support the hypothesis that oxidative stress, increased lipid peroxidation and depletion of antioxidant defenses are of critical importance in the pathogenesis of gastric mucosal injury in CRS-induced gastric ulcer. In agreement with previous studies, Tandon et al., 2004; Govindarajan et al., 2006; Chakraborti et al., 2007; Dekanski et al., 2009; Mei et al., 2011, we have observed a rise in MDA levels and depletion in antioxidant enzymes pool, as is evident to the declined activity of SOD, CATA, and GSH. 
Moreover, increased total acidity and proteolytic activity associated with reduction in the gastric juice $\mathrm{pH}$ values were observed in the present study and were correlated with the progressive development of ulcers, as indicated by increased ulcer index. These were in harmony with li et al., (2006) and Dekanski et al., (2009) who emphasized that, gastric acid can mediate acute gastric mucosal lesions induced by the stress ulcers, and that UI was negatively related with $\mathrm{pH}$ value. Additionally, stress is probably accompanied by release of histamine which in turn increases gastric secretion and causes disturbance of gastromucosal macrocirculaion, alteration in motility and reduced production of mucous. Vagal activity has been suggested as the main factor in stress induced ulceration, as it stimulates $\mathrm{HCl}$ in the stomach through the action of acetylcholine (ACh) acting through muscuranic receptors. During stress vagal activity was upregulated, resulting in the production of more acid. Further stress also causes mast cell degranulation. They concluded that, stasis of acid due to stress and over production of gastric acid increased volume are important factors involved in ulcer formation (Xie et al., 2005; Chaturvedi et al., 2007; Venkat et al., 2011).

Another important factor responsible for gastric injury is the weakening of defensive mucosal barrier. The essential criterion, which determines the status of mucosal defense barrier against the offensive assault of acid-pepsin, is the quantity of gastric mucus secretion. Increased mucus secretion by the gastric mucosal cells can prevent gastric ulceration by several mechanisms, including lessening stomach wall friction during peristalsis and acting as an effective barrier to the back diffusion of hydrogen ions (li et al., 2006; Martin and Wallace, 2006; Saxena et al., 2011). $\mathrm{PGE}_{2}$ is a well-established mediator in gastric mucosal defense and repair as it maintain the integrity of the gastric mucosa by stimulating secretion of the mucus and bicarbonate, modulating mucosal blood flow (Heeba et al., 2009; Mabrouk et al., 2009; Venkat et al., 2011) and inhibiting the neutrophil-mediated free radicals generation (Banerjee $\boldsymbol{e t}$ al., 2008). Stress is associated with weakening of defensive mucosal barrier, thus exposing the stomach to assault of ulcerogens (Brzozowski et al., 2007, 2008; Saxena et al., 2011). In the present study concurrent with previous observations (Chaturvedi et al., 2007; Dekanski et al., 2009), CRS-induced gastric ulcer was associated with inhibition of gastric mucosal $\mathrm{PGE}_{2}$ synthesis.

There is growing evidence that the components of renin- angiotensin system are present in many organs, including the stomach (Carl-McGrath et al., 2009). Ang II, the most active factor in this system, is a major stress hormone that, in the last few years has been implicated as the main causative factor in stress- induced gastric ulceration (Bregonzio et al., 2008), causing induction of oxidative stress (Cai $\boldsymbol{e t}$ al., 2003) and activation of inflammatory cascades, which is responsible for further gastric mucosal injury (Bregonzio et al., 2004). It was believed that, $\mathrm{AT}_{1}$ receptor stimulation by Ang II during stress is a major factor in the production of gastric injury. Under these conditions, feedback regulatory mechanisms that could include stimulation of synthesis and release of the injury-protective $\mathrm{PGE}_{2}$ are not sufficient to prevent stress- and Ang II-induced gastric damage unless $\mathrm{AT}_{1}$ receptors are blocked (Bregonzio et al., 2003).

In consistent with findings from previous studies that evaluated $\mathrm{AT}_{1}$ receptors blockers and their role in CRS- induced gastric ulceration (Bregonzio et al., 2003, 2004, 2008; Saavedra and Benicky , 2007; Pavel et al., 2008; Merai et al., 2009), our results demonstrate that pretreatment with $\mathrm{AT}_{1}$ receptor antagonist dramatically decreases the number of ulcerations produced by CRS, protecting the gastric mucosa from stress-induced injury, and that this ulcer protective activity arises from their effects on both offensive and defensive factors. The mechanism of their gastro-protective activity may be attributed to the reduction in free radical generation, and lipid peroxidation, inhibition of the pro-inflammatory cascade, reduction in MPO activity and suppression of acid and pepsin levels along with 
strengthening of the gastric mucosal defense by preserving the protective mechanisms, including $\mathrm{PGE}_{2}$ level.

Moreover, our results demonstrate that, telmisartan seems to provide superior gastroprotection to candesartan that affords more gastroprotection in comparison to olmesartan. Other mechanisms independent of the $\mathrm{AT}_{1}$ receptor blockade are responsible for this superior antioxidant, anti-inflammatory activities and anti-ulcerogenic effects of telmisartan. Telmisartan was known by its high affinity and partial agonistic effect at PPAR- $\gamma$ that was attributed to its high lipophilicity (Benson et al., 2004; Schupp et al., 2006; Fouad et al., 2010). Schupp and his colleagues , (2004); Ernsberger and Koletsky in (2007) emphasized that, PPAR-activating potency of certain ARBs correlates with their degree of lipophilicity to obtain sufficiently high penetration rates to bind to intracellular PPAR- $\gamma$ and exert selective PPAR modulators (SPPARM) activity (Schupp et al., 2005). PPAR- $\gamma$ activation is added to the gastroprotective effects of telmisartan by opposing the oxidative stress and inflammatory cascades induced by Ang II (Fouad et al., 2010). Moreover, previous studies emphasized that PPAR- $\gamma$ activation is associated with downregulation of $\mathrm{AT}_{1} \mathrm{R}$ that consequently attenuates the cellular response to Ang II (Imayama et al., 2006; Yousefipour et al., 2007; Zhao et al., 2008). So, the dual function of telmisartan ( $\mathrm{AT}_{1}$ receptor antagonism and PPAR activation), results in more complete inhibition of the Ang II. The gastroprotective role of PPAR- $\gamma$ activation were justified by Brzozowski et al., 2005; Fouad et al., 2010; Konturek et al., 2010; Morsy et al., 2010.

In conclusion, the present findings demonstrate that telmisartan, candesartan and olmesartan protected rats' gastric mucosa from CRS-induced ulcerations most possibly through their anti-oxidant activity, anti-secretory actions and enhanced mucosal protection. Furthermore, telmisartan seems to provide superior gastroprotection than candesartan and olmesartan. Activation of PPAR- $\gamma$ might be one potential AT1-independent mechanism of action that explains this superiority.

ACKNOWLEDGMENTS: Thanks to Dr. Dina M. Abo-Elmatty, assistant Prof. of Biochemistry, Faculty of Pharmacy, Suez Canal University.

\section{REFERENCES}

Aebi, H. 1984: Catalase in vitro. Meth. Enzymol. 105: 121-126.

Agnihotri, N., Kaur, H., Kaur, N., and Sarotra, P. 2007: Role of oxidative stress in lansoprazole-mediated gastric and hepatic protection in wistar rats. Ind.J. Gastroenterol. 26: 118-121.

Alsarra, I., Ahmed, M., Alanazi, F., Hussein, K., Alsheikh, A., and Neau, S. 2010: Influence of cyclodextrin complexation with NSAIDs on NSAID/cold Stress-induced gastric ulceration in rats. Int. J. Med. Sci. 7: 232-239.

Banerjee, D., Bauri, A., Guha, R., Bandyopadhyay, S., and Chattopadhyay, S. 2008: Healing properties of malabaricone B and malabaricone $C$, against indomethacininduced gastric ulceration and mechanism of action. Eur. J. Pharmacol. 578: 300312.

Benson, S., Pershadsingh, H., Ho, C., Chittiboyina, A., Desai, P., Pravenec, M., et al. 2004: Identification of telmisartan as a unique angiotensin II receptor antagonist with selective PPAR $\gamma$-modulating activity. Hypertension J. 43: 993-1002. 
Bogdanova, O., Kot, L., Lavrova, K., Bogdanov, V., Sloan, E., Beregova, T., et al. 2010: Modulation of protein tyrosine phosphorylation in gastric mucosa during reepithelization processes. World J. Biol. Chem. 1: 338-347.

Bregonzio, C., Armando, I., Ando, H., Jezova, M., Baiardi, G., and Saavedra, J. 2003: Antiinflammatory effects of angiotensin II $\mathrm{AT}_{1}$ receptor antagonism prevent stressinduced gastric injury. Am. J. Physiol. Gastrointest. Liver Physiol. 285: 414- 423.

Bregonzio, C., Armando, I., Ando, H., Jezova, M., Baiardi, G., and Saavedra, J. 2004: Angiotensin II $\mathrm{AT}_{1}$ receptor blockade prevents gastric ulcers during cold-restraint stress. Ann. Acad. Sci. 1018: 351-355.

Bregonzio, C., Seltzer, A., Armando, I., Pavel, J., and Saavedra, M. 2008: Angiotensin II $\mathrm{AT}_{1}$ receptor blockade selectively enhances brain $\mathrm{AT}_{2}$ receptor expression, and abolishes the cold-restraint stress-induced increase in tyrosine hydroxylase mRNA in the locus coeruleus of spontaneously hypertensive rats. Stress 11: 457-466.

Brzozowski, T., Konturek, P., Drozdowicz, D., Konturek, S., Zayachivska, O., Pajdo, R., et al. 2005: Grapefruit-seed extract attenuates ethanol-and stress-induced gastric lesions via activation of prostaglandin, nitric oxide and sensory nerve pathways. World J. Gastroenterol. 11: 6450-6458.

Brzozowski, T., Konturek, P., Pajdo, R., Kwiecie, S., Konturek, S., Targosz, A., et al. 2005: Agonist of peroxisome proliferator-activated receptor gamma (PPAR-gamma): a new compound with potent gastroprotective and ulcer healing properties. Inflammopharmacol. 13: 317-330.

Brzozowski, T., Zwirska-Korczala, K., Konturek, P., Konturek, S., Sliwowski, Z., Pawlik, M., et al. 2007: Role of circadian rhythm and endogenous melatonin in pathogenesis of acute gastric bleeding erosions induced by stress. J. Physiol. Pharmacol. 58: 53-64.

Brzozowski, T., Konturek, P., Chlopicki, S., Sliwowski, Z., Pawlik, M., Ptak-Belowska, A., et al. 2008: Therapeutic potential of 1-methylnicotinamide against acute gastric lesions induced by stress: role of endogenous prostacyclin and sensory nerves. J. Pharmacol. Exp. Ther. 326: 105-116.

Cai, H., Griendling, K., and Harrison, D. 2003: The vascular NAD(P)H oxidases as therapeutic targets in cardiovascular diseases. Trends Pharmacol. Sci. 24: 471478.

Carl-McGrath, S., Grantzdorffer, I., Lendeckel, U., Ebert, M., and Rocken, C. 2009: Angiotensin II-generating enzymes, angiotensin-converting enzyme (ACE) and mast cell chymase (CMA1), in gastric inflammation may be regulated by $\mathrm{H}$. pylori and associated cytokines. Pathol. J. 41: 419-427.

Chakraborti, A., Gulati, K., Banerjee, B., and Ray, A. 2007: Possible involvement of free radicals in the differential neurobehavioral responses to stress in male and female rats. Behav. Brain Res. 179: 321-325.

Chaturvedi, A., Mohan, K., Bhawani, G., Chaturvedi, H., Kumar, M., and Goel, R. 2007: Effect of ethanolic extract of eugenia jambolana seeds on gastric ulceration and secretion in rats. Ind. J. Physiol. Pharmacol. 51: 131-140.

Debnath, P.K., Gode, K.D., Govinda, D., and Sanyal, A.K. 1974: Effects of propanolol on gastric secretion in albino rats. Br. J. Pharmacol. 51: 213-216. 
Dekanski, D., Janićijević-Hudomal, S., Ristić, S., Radonjić, N., Petronijević, N., Piperski, $V$, et al. 2009: Attenuation of cold restraint stress-induced gastric lesions by an olive leaf extract. Gen. Physiol. Biophys. 28: 135-142.

Ellman, G.L.1970: SH groups determination in biological fluids. Anal. Biochem. 46: 237240.

Ernsberger, P., and Koletsky, R. 2007: Metabolic actions of angiotensin receptor antagonists: PPAR- $\gamma$ agonist actions or a class effect?. Curr. Opin. Pharmacol. 7: 140-145.

Fouad, A., Al-Sultan, A., Yacoubi, M., and Gomaa, W. 2010: Ameliorative effects of telmisartan in diabetic rats with indomethacin-induced gastric ulceration. Eur. J. Pharmacol. 637: 162-170.

Govindarajan, R., Vijayakumar, M., Singh, M., Rao, C., Shirwaikar, A., Rawat, A., et al. 2006: Antiulcer and antimicrobial activity of Anogeissus latifolia. J. Ethnopharmacol. 106: 57-61.

Heeba, G., Hassan, M., and Amin, R. 2009: Gastroprotective effect of simvastatin against indomethacin-induced gastric ulcer in rats: role of nitric oxide and prostaglandins. Eur. J. Pharmacol. 607: 188-193.

Imayama, I., Ichiki, T., Inanaga, K., Ohtsubo, H., Fukuyama, K., Ono, H., et al. 2006: Telmisartan downregulates angiotensin II type 1 receptor through activation of peroxisome proliferator -activated receptor $\gamma$. Cardiovasc. Res. 72: 184-190.

Iwamoto, K., Watanabe, J., and Atsumi, F. 1987: Effects of urethane anesthesia and age on organ blood flow in rats measured by hydrogen gas clearance method. J. Pharmacobiodynam. 10: 280-284.

Kakadiya, J., Brambhatt, J., and Shah, N. 2010: Renoprotective activity of pioglitazone on ischemia/ reperfusion induced renal damage in diabetic rats. Rec. Res. Sci. and Tech. 2: 92-97.

Konturek, P., Sliwowski, Z., Koziel, J., Ptak-Belowska, A., Burnati, G., Brzozowski, T., et al. 2009: Probiotic bacteria Escherichia coli strain nissle 1917 attenuates acute gastric lesions induced by stress. J. physiol. Pharmacol. 60: 41-48.

Konturek, P., Brzozowski, T., Burnati, G., Szlachcic, A., Koziel, J., Kwiecien, S., Konturek, S., Harsch, A. 2010: Gastric ulcer healing and stress- lesion preventive properties of pioglitazone are attenuated in diabetic rats. J. physiol. Pharmacol. 61: 429-436.

Kulkarni, S.K. 1999: Experiments on intact preparations (in-vivo studies). In: Handbook of Experimental pharmacology, 3 rd Edition. Delhi, Vallabh Prakashan : PP.148180.

Li, Y., Lu, G., Zou, X., Li, Z., Peng, G., and Fang, D. 2006: Dynamic functional and ultrastructural changes of gastric parietal cells induced by water immersionrestraint stress in rats. World J. Gastroenterol. 12: 3368-3372.

Mabrouk, M., Nnawodu, F., Tanko, Y., Dawud, F., and Mohammed, A. 2009: Effect of aqueous garlic $(\mathrm{Ag})$ extract on aspirin induced gastric mucosal lesion in albino wistar rats. Curr. Res. J. of Biological Sci. 1: 15-19.

Manas, D., Sanjita, D., Papiya, M., and Saumya, D. 2010: Comparative study of Captopril and Losartan on gastric ulcer in rats. Int. J. Pharmacy Res. 1: 1-6.

Marklund, S.L.1992: Regulation by cytokines of extracellular superoxide dismutase and other superoxide dismutase isoenzymes in fibroblasts. J. Biol. Chem. 267: 96-102. 
Martin, G., and Wallace, J. 2006: Gastrointestinal inflammation: a central component of mucosal defense and repair. Exp. Biol. Med. 231:130-137.

Mei, $X ., X u, D ., X u, S ., Z h e n g, Y$., and $X u, S$. 2011: Gastroprotective and antidepressant effects of a new zinc (II)-curcumin complex in rodent models of gastric ulcer and depression induced by stresses. J. Pharmacol. Biochem. and Behav. 99: 66-74.

Merai, A., Asad, M., and Prasad, V. 2009: Effect of centrally administered losartan on gastric and duodenal ulcers in rats. Pharmacol. J. 84: 93-98.

Mizutani, A., Okajima, K., Uchiba, M., Isobe, H., Harada, N., Mizutani, S., et al. 2003: Anti-thrombin reduces ischemia/reperfusion-induced renal injury in rats by inhibiting leucocyte activation through promotion of prostacyclin production. Hemostasis thromb. Vasc. Biol. 101: 3029-3036.

Morsy, M., Ashour, O., Fouad, A., and Abdel-Gaber, S. 2010: Gastroprotective effects of the insulin sensitizers, rosiglitazone and metformin, in indomethacin-induced gastric ulcer in type 2 diabetic rats. Clin. Exp. Pharmacol. Physiol. 37: 173-177.

Muthuraman, A., and Sood, S. 2010: Antisecretory, antioxidative and antiapoptotic effects of montelukast on pyloric ligation and water immersion stress induced peptic ulcer in rat. Prostaglandins Leukot. Essent. Fatty Acids 83: 55-60.

O'Malley, P. 2003: Gastric ulcers and GERD: the new "plagues" of the 21st century update for the clinical nurse specialist. Clin. Nurse Spec. 17: 286-289.

Oyagi, A., Ogawa, K., Kakino, M., and Hara, H. 2010: Protective effects of a gastrointestinal agent containing Korean red ginseng on gastric ulcer models in mice. B.M.C. Complement Altern. Med. 10: 10- 45.

Pavel, J., Benicky, J., Larrayoz-Roldan, I., Murakami, Y., Sanchez-Lemus, E., Zhou, J., et al. 2008: Peripherally administered Angiotensin II $\mathrm{AT}_{1}$ receptor antagonists are anti-stress compounds in vivo. Ann. Acad. Sci. 1148: 360-366.

Pershadsingh, H. 2004: Peroxisome proliferator-activated receptor-gamma: therapeutic target for diseases beyond diabetes: quo vadis?. Expert Opin. Invest. 13: 215-228.

Preuss, H.G., Jarrel, S.T., Scheckenobach, R., Lieberman, S., and Anderson, R.A. 1998: Comparative effects of chromium vanadium and Gymnema sylvestre on sugarinduced blood pressure elevations in SHR. J. Am. Coll. Nutr. 17: 116-123.

Saavedra, J., and Benicky, J. 2007: Brain and peripheral angiotensin II play a major role in stress. Stress 10: 185-193.

Saxena, B., Krishnamurthy, S., and Singh, S. 2011: Gastroprotective potential of risperidone, an atypical antipsychotic, against stress and pyloric ligation induced gastric lesions. Chemico- Biol. interactions J. 190: 155-164.

Schupp, M., Pharm, B., Janke, J., Clasen, R., Unger, T., and Kintscher, U. 2004: Angiotensin type 1 receptor blockers induce peroxisome proliferator-activated receptor- gamama activity. Circulation J. 109: 2054-2057.

Schupp, M., Clemenz, M., Gineste, R.,Witt, H., Janke, J., Helleboid, S., et al. 2005: Molecular characterization of new selective peroxisome proliferator-activated receptor _ modulators with angiotensin receptor blocking activity. Diabetes J. 54: 3442-3452. 
Schupp, M., Lee, L., Frost, N., Umbreen, S., Schmidt, B., Unger, T., et al. 2006: Regulation of peroxisome proliferator-activated receptor gamma activity by losartan metabolites. Hypertension J. 47: 586-589.

Singh, S., Khajuria, A., Taneja, S.C., Khajuria, R.K., Singh, J., Johri, R.K., et al. 2008: The gastric ulcer protective effect of boswellic acids, a leukotriene inhibitor from boswellia serrata in rats. Phytomed. 15: 408-415.

Sukumaran, V., Watanabe, K., Veeraveedu, P., Thandavarayan, R., Gurusamy, N., Ma, M., et al. 2010: Beneficial effects of olmesartan, an angiotensin II receptor type 1 antagonist, in rats with dilated cardiomyopathy. Exp. Biol. Med. 235: 1338-1346.

Sumbul, S., Ahmad, M.A., Mohd, A., and Mohd, A. 2011: Role of phenolic compounds in peptic ulcer: An overview. J. Pharm. Bioallied. Sci. 3: 361-367.

Tandon, R., Khanna, H., Dorababu, M., and Goel, R. 2004: Oxidative stress and antioxidants status in peptic ulcer and gastric carcinoma. Ind. J. Physiol. Pharmacol. 48:115-118.

Venkat, N., Venu, K., Sowmya, U., Reddy, J., and Anirudh, K. 2011: Evaluation of antiulcer activity of Momordica Charantia in rats. Inter. J. Pharmacy and Biological Sci. 1: 1-16.

Wada K, Nakajima A, Takahashi H, Yoneda M, Fujisawa N, Ohsawa E, et al. 2004: Protective effect of endogenous PPAR gamma against acute gastric mucosal lesions associated with ischemia-reperfusion. Am. J. Physiol. Gastrointest. Liver Physiol. 287: G452-G458.

Xie, Y., Jiao, Q., Guo, S., Wang, F., Cao, J., and Zhang, Z. 2005: Role of parasympathetic overactivity in water immersion stress-induced gastric mucosal lesion in rat. J. Appl. Physiol. 99: 2416-2422.

Yousefipour, Z., Hercule, H., Truong, L., Oyekan, A., and Newaz, M. 2007: Ciglitazone, a peroxisome proliferator-activated receptor _inducer ameliorates renal preglomerular production and activity of angiotensin II and thromboxane $\mathrm{A}_{2}$ in glycerol-induced acute renal failure. J. pharmacol. Exp. Therap. 322: 461-468.

Zhang, F., Liu, F. , Yan, M., Ji, H. , Hu, L. , Li, X., et al. 2010: Peroxisome proliferatoractivated receptor- $\gamma$ agonists suppress iNOS expression induced by LPS in rat primary schwann cells. J. Neuroimmunol. 218: 36-47.

Zhao, S., Shen, L., Li, H., Wang, L., Chen, H., Wang, Y., et al. 2008: Down-regulation of the expression of angiotensin II type 1 receptor in neonatal rat cardiac fibroblast by activation of PPARgamma signal pathway. Chin. J. Physiol. 51: 357-362.

Zhu, D., Shi, J., Zhang, Y., Wang, B., Liu, W., Chen, Z., et al. 2011: Central angiotensin II stimulation promotes $\beta$ amyloid production in Sprague Dawley rats. PLoS One J. 6: e16037. 
الداور الوقائى لتلميسارتان ولكنديسارتان أو لأولميسارتان على قرحة المعان المدة المستحدثة

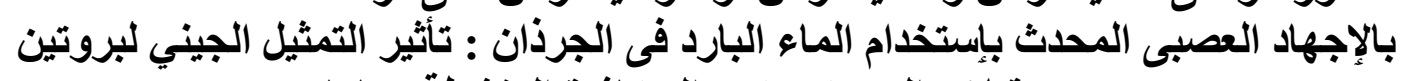

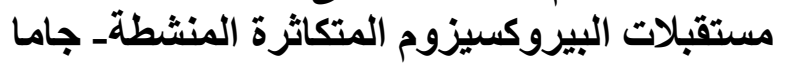

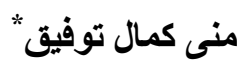

* قسم الأدوية ــ كلية الطب جامعة قناة السويس توني

تنثلك بعض غالقات مستقبلات الأنجيوتنسين خاصية القدرة على تحفيز مستقبلات البيروكسيزوم المتكاثرة

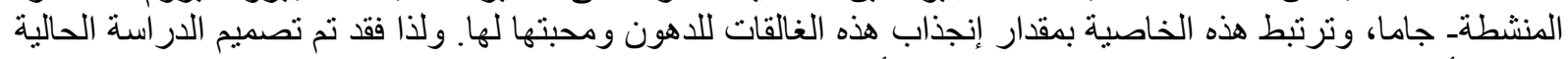

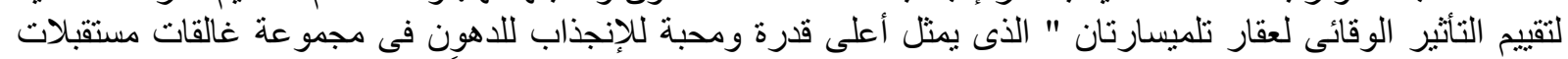

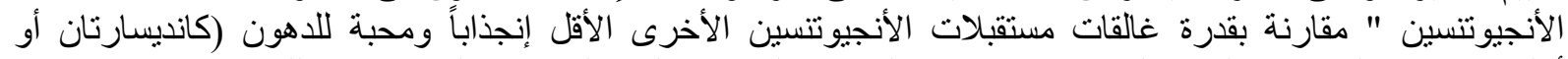

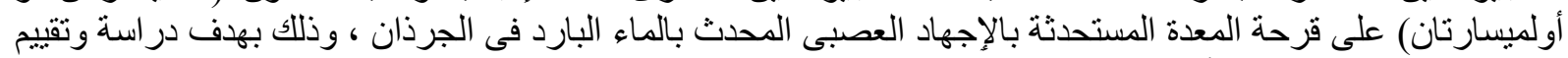

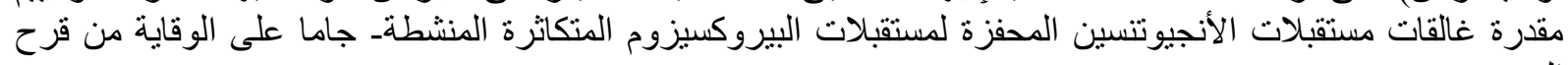

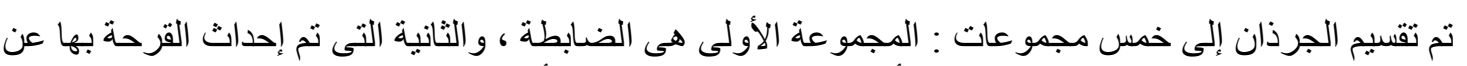
المعدة.

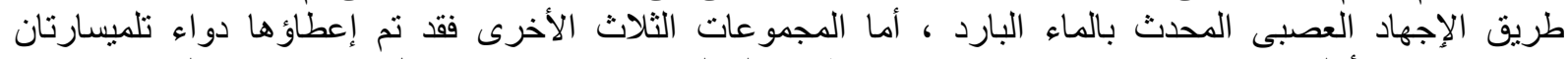

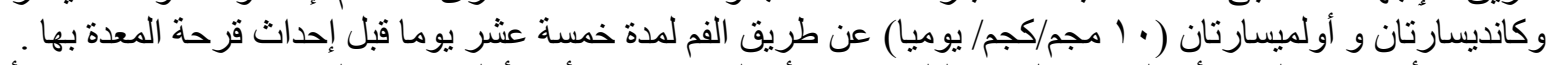

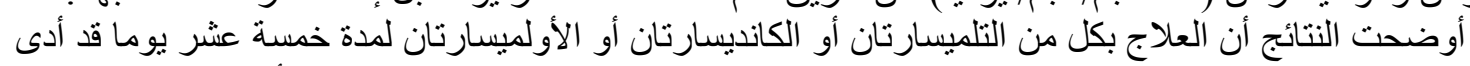

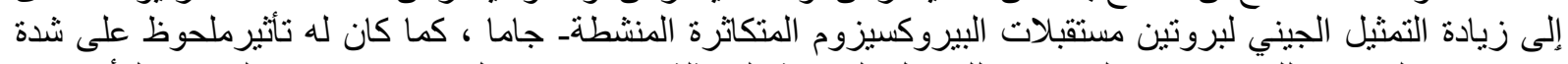

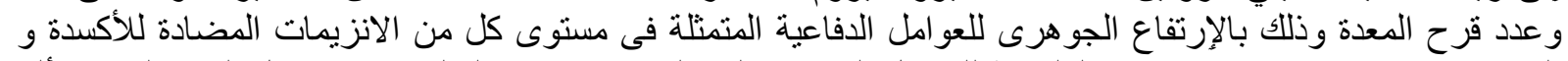

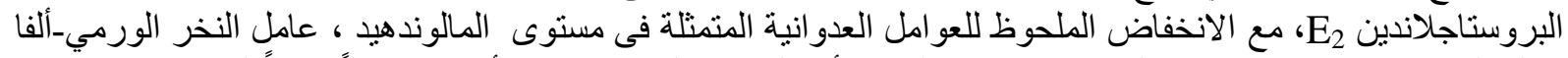

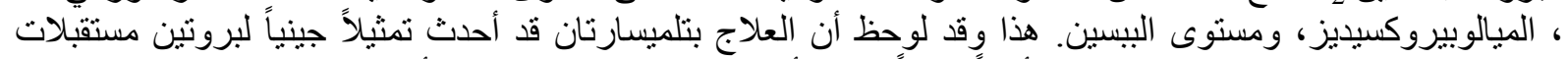

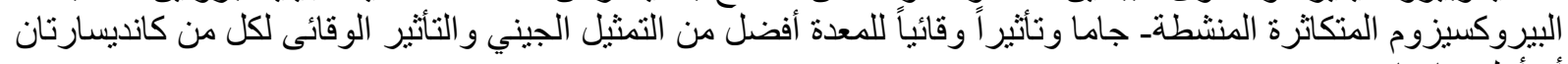

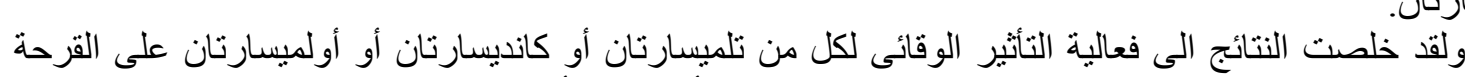

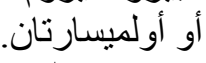

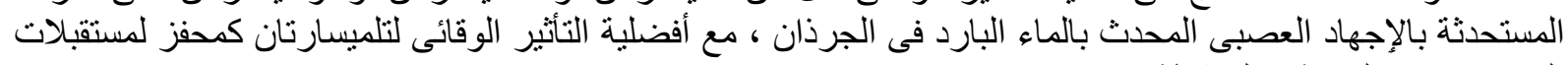

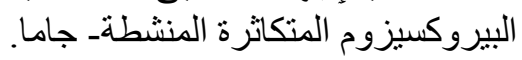

